УдК $575.12: 576.312 .32: 633.17$

I. I. Моцний ${ }^{1}$, к.б.н., провідний науковий співробітник,

I. С. Петрова ${ }^{2}$ студентка,

Г. О. Чеботар ${ }^{1}$, к.б.н., співробітник,

C. В. Чеботар ${ }^{1,2}$, д.б.н, провідний науковий співробітник

${ }^{1}$ Селекційно-генетичний інститут - Національний центр насіннєзнавства та сортовивчення,

Овідіопольська дор., 3, Одеса, 65036, Україна, e-mail: motsnyyii@gmail.com.

${ }^{2}$ Одеський національний університет імені I. І. Мечникова, кафедра генетики та молекулярної біології

вул. Дворянська, 2, Одеса, 65082, Україна, e-mail: s.v.chebotar@gmail.com

\title{
ВПЛИВ ХРОМОСОМИ ELYMUS SIBIRICUS НА АГРОНОМІЧНI ОЗНАКИ У ДИСОМНО-ДОПОВНЕНОЇ ЛІНІЇ ОЗИМОЇ М'ЯКОЇ ПШЕНИЦІ
}

Оцінено відмінності між виділеною з сорту озимої м'якої пшениці «Обрій» чистою лінією та створеною на іï базі дисомно-доповненою лінією «О27-2», що несе чужинні ознаки стійкості до листової іржі та опушення листової пластинки від амфіплоїда Elytricum fertile. Визначено переважно негативний вплив чужинної хромосоми на характеристики головного колосу (довжина, кількість колосків та зерен, маса зерна), висоту рослин, кількість та масу зерна з підгонів. Проте, стосовно таких ознак, як продуктивне кущення, довжина головного колоса, кількість колосків в головному колосі, маса зерна з головного колосу, 3 підгонів і, в цілому, з рослини - зазначений вплив суттєво модифікується умовами року. Доповнена лінія характеризувалася вищою масою тисячі зерен, порівняно з рекурентною формою. Зазначена хромосома суттево підвищує стійкість рослин до листової іржі, проте ніяк не впливає на реакцію рослин на ураження борошнистою росою, жовтою і стебловою іржею, септоріозом, ВЖКЯ, до яких обидві лінії проявили сприйнятливість.

Ключові слова: Triticum aestivum L., Elytricum fertile, доповнені лінії, кількісні ознаки.

Збагачення генофонду сучасних сортів м'якої пшениці шляхом інтрогресії нових генів, що детермінують господарсько-корисні ознаки, від дикорослих видів - це одна із задач прикладної генетики пшениці. Ефективність подальшого практичного використання інтрогресованих генів суттєво залежить від розміру чужинного сегменту, зумовленого, значною мірою, дивергентністю хромосом стороннього виду від хромосом пшениці. Тому, велика частка одержаного внаслідок віддаленої гібридизації експериментального матеріалу часто наряду 3 позитивними ознаками, привнесеними в геном пшениці (головним чином, стійкість до біотичних/абіотичних стресів), має багато недоліків, що знижує результативність інтрогресивної селекції [17]. 
Залучення видів з третього, за класифікацією E. R. Sears [18], генного пулу філогенетично найвіддаленіших від пшениці - видається найскладнішим, але необхідним засобом інтрогресивної селекції у випадку, якщо вони мають потрібні господарсько-цінні гени. У цьому відношенні можливими джерелами цінних ознак для пшениці традиційно вважаються, види 3 родів Agropyron Gaertn (пирій) та Elymus L (пирійник), час використання яких в колишньому СРСР і Канаді наближається уже до 100-річчя $[2,19]$. Оскільки пирійник важко схрещується $з$ пшеницею, для подолання несумісності, а також стерильності гібридів $\mathrm{F}_{1}$, доцільно залучати проміжні форми за його участю, зокрема амфідиплоїди з пшеницею, які об'єднують диплоїдні набори хромосом обох видів. Однак амфідиплоїди, як відомо, не можна відразу використовувати в селекції, через велику кількість небажаних ознак, зумовлених, зокрема, взаємодією між чужинним і пшеничним геномами [8].

Для усунення проблем, пов'язаних з наявністю повного чужинного геному, можна добавляти в комплемент пшениці окремі його хромосоми і створювати доповнені лінії. У випадку повного відновлення пшеничного генофону сортудонора такі лінії можуть слугувати модельним об'єктом для напрацювання молекулярних методів ідентифікації і маркування чужинних хромосом, визначення їх впливу на агрономічні і кількісні ознаки, локалізації і картування чужинних морфологічних ознак та розробки алгоритмів генетичного аналізу якісних ознак, що контролюються непарними хромосомами. При цьому присутність інтактної чужинної хромосоми досить легко детектується рутинним ацетокарміновим методом [11]. Успішність же практичного використання тієї чи іншої доповненої лінії залежить від трьох іiї властивостей: 1) цитологічної стабільності; 2) фертильності; 3) відсутності негативного впливу доповненої хромосоми на господарсько цінні ознаки (якість зерна, структура врожаю) [3].

Відомо, що опушення листа служить ефективним захистом пшениці від приховано стеблових (шведська муха) і листогризучих (хлібні блішки, п'явиця) шкідників [5]. Відомо також, що опушення - це ксероморфна ознака, притаманна рослинам сухих місцевостей, яка забезпечує стійкість до посухи шляхом зниження інтенсивності транспірації і затримує рух гарячого повітря безпосередньо на поверхні опушених органів [10]. Опушені поверхні краще затримують вологу дощу і роси. Однак, останнє сприяє розвитку грибкових хвороб, навіть в сухих умовах вирощування. Тому, підвищувати посухостійкість пшениці шляхом опушення iї органів необхідно в комплексі зі стійкістю до хвороб [15].

Збудником бурої листової іржі пшениці є дводомний гриб Puccinia recondite Rob. ex Desm. f. sp. tritici. Захворювання призводить до руйнування хлорофілу, зменшення асиміляційної поверхні листків і передчасного їх засихання. У літературі констатується диференціація втрат урожаю зернових колосових культур залежно від часу появи, умов року, інтенсивності навантаження та расового складу хвороби $[1,6,12]$. $€$ багато даних, які свідчать про неможливість вирішення проблеми стійкості пшениці до іржі на основі одних лише міжсортових 
схрещувань. Тому виникає необхідність пошуку нових, більш ефективних методів. В літературі описано успішну передачу стійкості до жовтої, бурої та стеблової іржі пшениці від диких злаків шляхом перенесення хромосом [13, 14].

Мета даної роботи - визначення впливу хромосоми Elymus sibiricus, яка несе гени стійкості до листової іржі та опушення листової пластинки на агрономічні ознаки пшениці у дисомно-доповненої лінії озимої м’якої пшениці «О27-2».

\section{Матеріал та методи дослідження}

При виконанні роботи було використано чисту лінію, виділену методом багатократного індивідуального добору з сорту озимої м'якої пшениці «Обрій» $(2 n=42$, рис. 1 а) та одержану на її основі дисомно-доповнену лінію «O27-2» $(2 n=44)$. Лінія «О27-2» була створена 3 метою інтрогресії в пшеницю чужинних ознак стійкості до листової іржі і опушення листової пластинки (фактор стійкості до шкідників і посухостійкості). При створенні лінії «О27-2» в якості материнського та в подальшому рекурентного компонента для схрещення використовували лінію «Обрій». В якості донора ознак використовували неповний пшенично-елімусний амфідиплоїд (HПЕА) Elytricum fertile (згідно з наявним родоводом - Triticum aestivum L., $2 n=42$, AABBDD ' Elymus sibiricus L., $2 n=$ $\left.28, \mathrm{~S}^{\mathrm{t}} \mathrm{HH}\right)$, який був люб' язно наданий В. К. Симоненку д-ром R. Franke (ФРН) під час наукового відрядження. Методом геномної in situ гібридизації (GISH) д-ром Г. Федаком (Канада) установлено, що амфіплоїд має 42 хромосоми пшениці і 14 хромосом пирійника. При чому всі чужинні хромосоми належать до одного геному $\left(\mathrm{S}^{t}\right)$ [G. Fedak, 2000 особисте повідомлення]. Таким чином, геномна формула HПЕА Elytricum fertile має вигляд $2 n=8 \mathrm{x}=56$, AABBDDSt ${ }^{t}$ ).

Виконувалась серія насичувань до $\mathrm{BC}_{8}$ під перманентним цитологічним, фітопатологічним і фенотиповим контролем. При кожному схрещенні добирались рослини $\left(2 n=43 ; 21_{\mathrm{w}}{ }^{\mathrm{II}}+1_{\mathrm{e}}{ }_{\mathrm{e}}^{\mathrm{I}}\right)$ з вище вказаними ознаками (рис. 1 б). При цьому було доказано, що досліджувані ознаки некротичної стійкості до листової іржі і сильного опушення верхньої поверхні листової пластинки контролюються локалізованими в одній хромосомі $\mathrm{S}^{\mathrm{t}}$ геному E. sibiricus генами $L r^{e}$ та $H l^{e}$, відповідно, і можуть слугувати її фенотипічними маркерами. Насичування проводилось від індивідуальної рослини 27-94 (ВС 1 («Обрій» х Elytricum fertile) x «Обрій») з максимальним проявом чужинних ознак. Під час насичувань частота передачі доповненої чужинної хромосоми через яйцеклітину $(22,7 \%$ в середньому; з варіацією по роках - 7,0-28,6 \%) і $з$ пилком (4,8 \% - в середньому; з варіацією по роках - 0-10,7 \%) була занижена. Навесні 2003 р., відразу після чергового бекросу без самозапилення за рахунок нерозходження чужинної хромосоми в AII з подальшим відходженням обох іiі хроматид до складу одного ядра тетрад отримана одна рослина $\mathrm{BC}_{8}\left(2 n=44 ; 22^{\text {II }}\right) 3$ результативними чужинними ознаками (рис. 1 в). Ця рослина стала засновником дисомнодоповненої лінії «О27-2» [9]. 


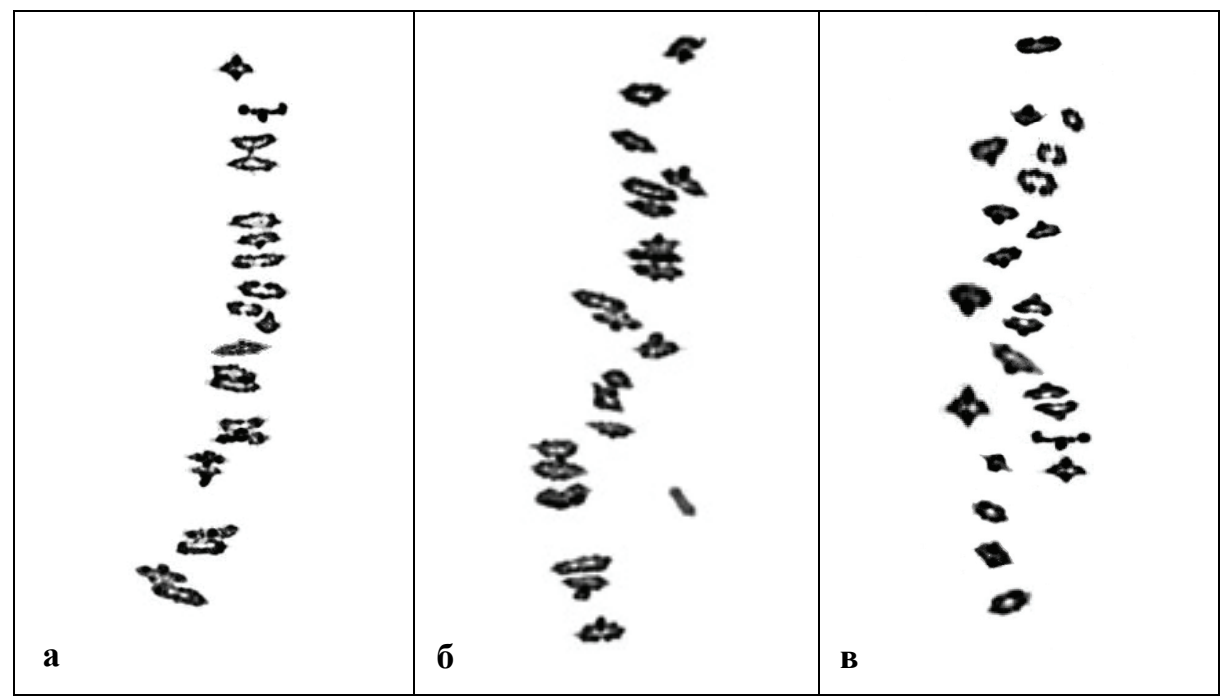

Рис. 1. Хромосомні пластинки на стадії МІ мейозу у досліджених гібридних та контрольних рослин (590×): а) рослина сорту «Обрій» без чужинних ознак $\left.\left(2 n=42 ; 21^{I I}\right) ; 6\right)$ моносомно-доповнена рослина $B C_{7}$ з опушенням листа та стійкістю до листової іржі $\left(2 n=43 ; 21^{I I}+1^{I}\right) ;$ в) дисомно-доповнена рослина $B C_{8}$ з опушенням листа та стійкістю до листової іржі $\left(2 n=44 ; 22^{I I}\right)$

Польові спостереження проводили протягом 2013-2014 рр. Матеріал сіявся 2-рядковими ділянками широкорядним способом ручною саджалкою на полі відділу загальної та молекулярної генетики СГІ - НЦНС. Довжина рядка 1,1 м, 3 міжряддям 30 см і відстанню між рослинами 5 см. Агротехніка загальноприйнята для насінницьких посівів зони Півдня України, попередник - чорний пар, ранньовесняне підживлення по таломерзлому грунту - аміачна селітра (з розрахунку - N 30 кг/га д.р.). Догляд за посівами та збирання врожаю проводили вручну.

Визначали наступні ознаки: «висота рослини» (ВР, см), «продуктивне кущення різних ярусів» $\left(П \mathrm{~K}_{1}, \Pi_{2}, \Pi_{3}\right)$, «довжина головного колоса» (ДГК, см), «кількість колосків у головному колосі» (ККК, шт.), «кількість фертильних колосків» (КФК, шт.), «кількість зерен у головному колосі» (ЗК, шт.), «маса зерна $з$ головного колосу» (МЗК, г), «кількість зерен з підгонів» (ЗП, шт.), «маса зерна 3 підгонів» (МЗП, г), «кількість зерен з рослини» (ЗР, шт.), «маса зерна 3 рослини» (МЗР, г), «маса тисячі зерен» (МТЗ), «маса тисячі зерен з головного колосу» (МТЗГ), «маса тисячі зерен з підгонів» (МТЗП), «щільність колоса» (ЩК), «кількість стерильних колосків» (КСК), «кількість зерен з колоса» (ЗКк).

Фітопатологічну оцінку проводили в польових умовах на фоні природних епіфітотій та штучному інфекційному фоні борошнистої роси (Blumeria 
graminis (DC) Speer f. sp. tritici March.), листової (Puccinia recondite Rob. ex Desm. f. sp. tritici Eriks. and Henn.), жовтої (Puccinia striiformis West.) та стеблової (Puccinia graminis f. sp. tritici Pers.) іржі, септоріозу (Septoria tritici Rob. ex Desm.) та ВЖКЯ (вірусу жовтої карликовості ячменю). Ступінь стійкості дорослих рослин оцінювали по 9-бальній інтегральній шкалі, де 9 балів означає дуже високий рівень стійкості: ураження рослин відсутнє, 1 бал - дуже висока сприйнятливість - ураження рослин - 100 \% і т. д. [7].

Для оцінки вірогідності отриманих результатів, статистичне опрацювання результатів дослідження проводили методом двофакторного дисперсійного аналізу за програмою Statistica 8. При цьому застосовувалась модель 3 вільними градаціями факторів «Рік» (як умови) і «Лінія». Вірогідність різниці між середніми значеннями визначали за допомогою найменшої істотної різниці (HIP) та довірчого інтервалу 95 \% рівня значимості [4]. Позначення маркерних ознак в таблицях і тексті наведені у відповідності 3 міжнародним каталогом генних символів [16].

\section{Результати та їх обговорення}

За допомогою двофакторного дисперсійного аналізу виявлено достовірний вплив взаємодії факторів «Рік» х «Лінія» для ознак ВР, ПК, ДГК, ККК, КФК, МЗК, МЗП і МЗР. Вплив фактора «Лінія», не зважаючи на взаємодію «Рік» х «Лінія», був достовірним для наступних ознак: висота рослини, число зерен, число фертильних колосків та кількість колосків в головному колосі (табл. 1). Відмінності між градаціями за фактором «Лінія» в основному зумовлені чужинною хромосомою з сильним негативним ефектом на кількісні ознаки [13].

За даними структурного аналізу за період 2013-2014 рр., виявлено чітку закономірність до зниження кількості зерен в головному колосі у лінії «О27-2», що видно 3 рис. 2А. Така ж закономірність простежувалася для наступних ознак: число фертильних колосків в головному колосі, кількість колосків в головному колосі та висота рослин (рис. 2Б, 2В, 2Г).

Необхідно зазначити, що за обидва роки висота рослини лінії О27-2 (2013 р. - 69,7 см, 2014 р. - 69,3 см) майже не змінилася, в той час як у лінії Обрій середнє значення за 2013 рік становить 72,0, а за 2014 - 79,4 см. Можливо, це зумовлено не залежним від умов року епістатичним впливом чужинної хромосоми на генотип рекурентного сорту за ознакою ВР.

Цікаво, що маса зерен в головному колосі дисомно-доповненої лінії «О27-2», порівняно 3 показниками сорту «Обрій» підвищилася в 2013 році (середне значення «Обрію» - 1,62, а «О27-2»-1,89 г), але значно зменшилася в 2014 (рис. 2 Б). Ці дані свідчать про те, що накопичення маси зерна залежить більшою мірою від сприятливих умов року (без стресів в період розвитку зерна). 
Результати дисперсійного аналізу отримані при дослідженні ліній «Обрій» та «О27-2» за два роки

\begin{tabular}{|c|c|c|c|c|}
\hline \multirow{2}{*}{ Ознака } & \multicolumn{4}{|c|}{ Джерело варіації, mS } \\
\hline & «Рік» $(\mathrm{df}=\mathbf{1})$ & «Лінія» $(\mathrm{df}=1)$ & $\begin{array}{c}\text { Взаємодія «Рік» } \mathrm{x} \text { «Лінія» } \\
(\mathrm{df}=\mathbf{1})\end{array}$ & $\begin{array}{c}\text { Похибка } \\
\text { (df=99) }\end{array}$ \\
\hline BP & $339,65 * *$ & $953,53 * * *$ & $252,51 * *$ & 35,2 \\
\hline ПК & $7,7 *$ & $\mathbf{0 , 1 8}$ & $\mathbf{0 , 0 2}$ & 1,77 \\
\hline ПК & 14,38 & 15,15 & 5,27 & 5,9 \\
\hline ПК & $27,34 *$ & 0,16 & $110,2 * * *$ & 5,27 \\
\hline ДГк & 1,13 & 0,05 & $8,89 * * *$ & 0,7 \\
\hline кКк & 0,16 & $201,42 * * *$ & $39,56 * * *$ & 2,11 \\
\hline КФК & 6,78 & $85,57 * * *$ & $29,4 * *$ & 4,3 \\
\hline ЗК & 65,5 & $1204,87 * * *$ & 100,88 & 150,4 \\
\hline МЗК & 0,06 & 0,13 & $1,01 *$ & 0,21 \\
\hline $3 \Pi$ & 53428 & 117143 & 119234 & 37600 \\
\hline мЗП & 18,75 & 13,44 & $243,96 * *$ & 35,6 \\
\hline 3P & 57235,79 & 142108 & 126271,88 & 40789,9 \\
\hline МЗР & 21,03 & 10,83 & $276,22 * *$ & 38,91 \\
\hline МT3 & $\mathbf{5 0 , 9 5}$ & $662,73^{*}$ & $156,09 * * *$ & 14,40 \\
\hline МТЗГ & 0,01 & $742,07 *$ & $155,65 * *$ & 18,96 \\
\hline мТзП & 9,44 & $583,25 *$ & $242,82 *$ & 18,79 \\
\hline ЩК & 4,22 & $277,39 *$ & 0,02 & 2,44 \\
\hline КСК & 4,85 & $24,42 *$ & 0,75 & 1,56 \\
\hline ЗКк & 0,01 & 0,25 & $\mathbf{0 , 0 5}$ & 0,19 \\
\hline
\end{tabular}

Примітки: * - достовірно при $\mathrm{P}=0,05 ;$ ** - достовірно при $\mathrm{P}=0,01$; *** - достовірно при $\mathrm{P}=0,001$ 


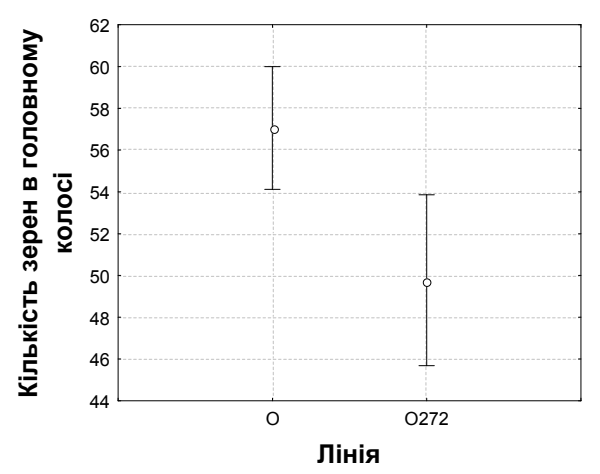

A
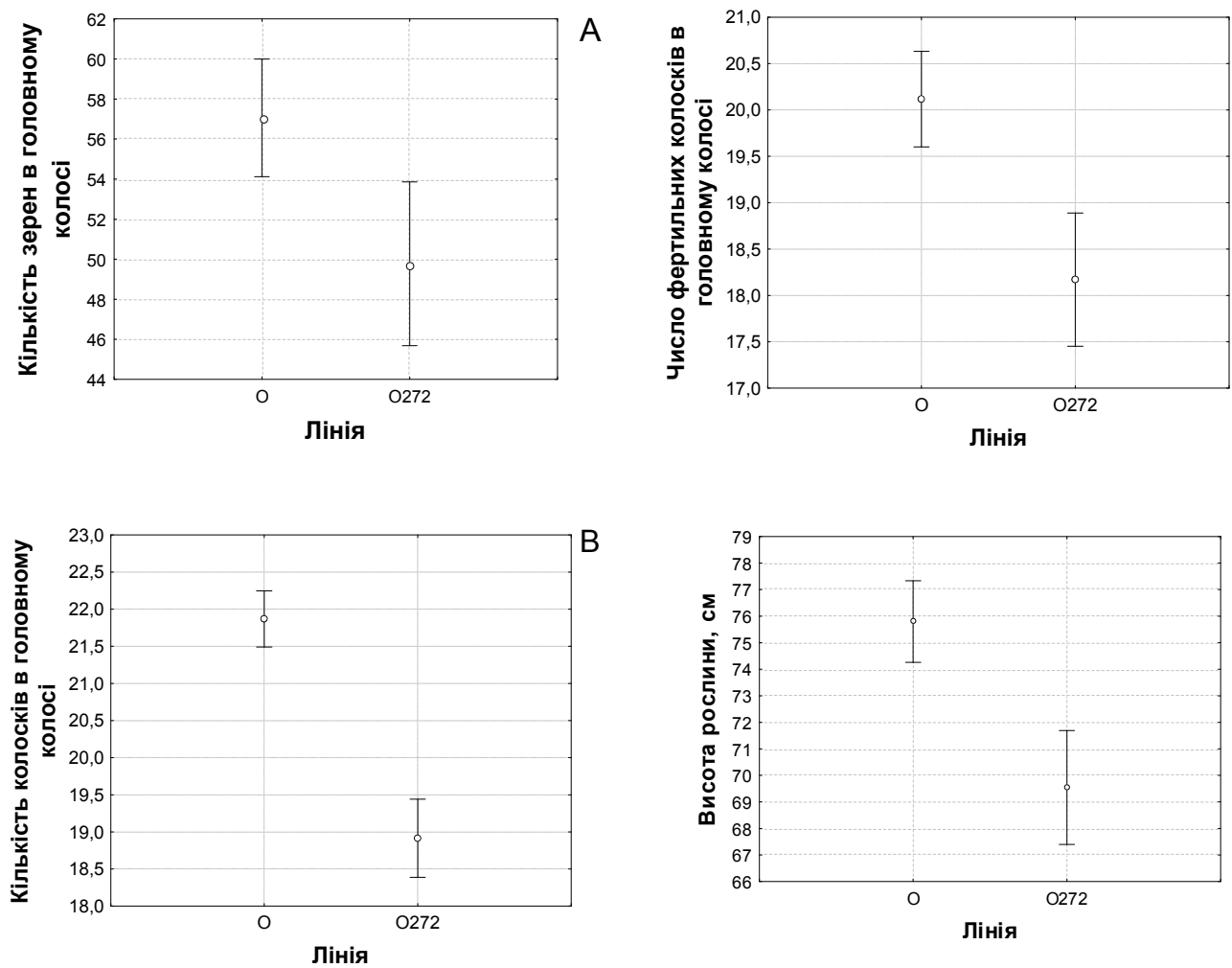

Рис. 2. Залежність показників ЗК (А), КФК (Б), ККК (В), ВР (Г) від фактора «Лінія» у порівняльних генотипах $O-$ «Обрій» $i$ «O27-2»

За два роки дослідження, крім суттєвого окремого впливу факторів «Лінія» i «Рік», виявлена достовірна $(\mathrm{p}<0,05)$ частка їх взаємодії («Рік» х «Лінія») в загальній дисперсії наступних ознак: маса зерен $з$ підгонів (А), маса зерен в головному колосі (Б), довжина головного колосу (В), маса зерен з рослини (Г) (рис. 3). Тобто негативний ефект доповненої хромосоми на ці ознаки проявлявся не кожного року, а лише в 2014 р. В той час як в умовах 2013 р. визначена чітка тенденція на покращення вказаних ознак за присутності чужинної хромосоми.

Таким чином, за даними дворічних досліджень чужинна хромосома, яка несе гени стійкості до листової іржі $\left(\mathrm{Lr}^{2}\right)$ та опушення листової пластинки $\left(H l^{e}\right)$, має негативні ефекти на низку біологічних та агрономічних ознак пшениці. За наявності цієї хромосоми у каріотипі спостерігається зменшення висоти рослин та її складових - довжини колоса та стебла. Кількість колосків 3 колоса зменшується за рахунок фертильних колосків, а кількість стерильних (крайніх недорозвинутих) колосків залишається майже незмінною (табл. 2). Ряд ознак змінюється як в сторону зменшення, так і збільшення, в залежності від умов року. В середньому, за період 2013-2014 рр. лінія «О27-2», в порівнянні $з$ ліні- 

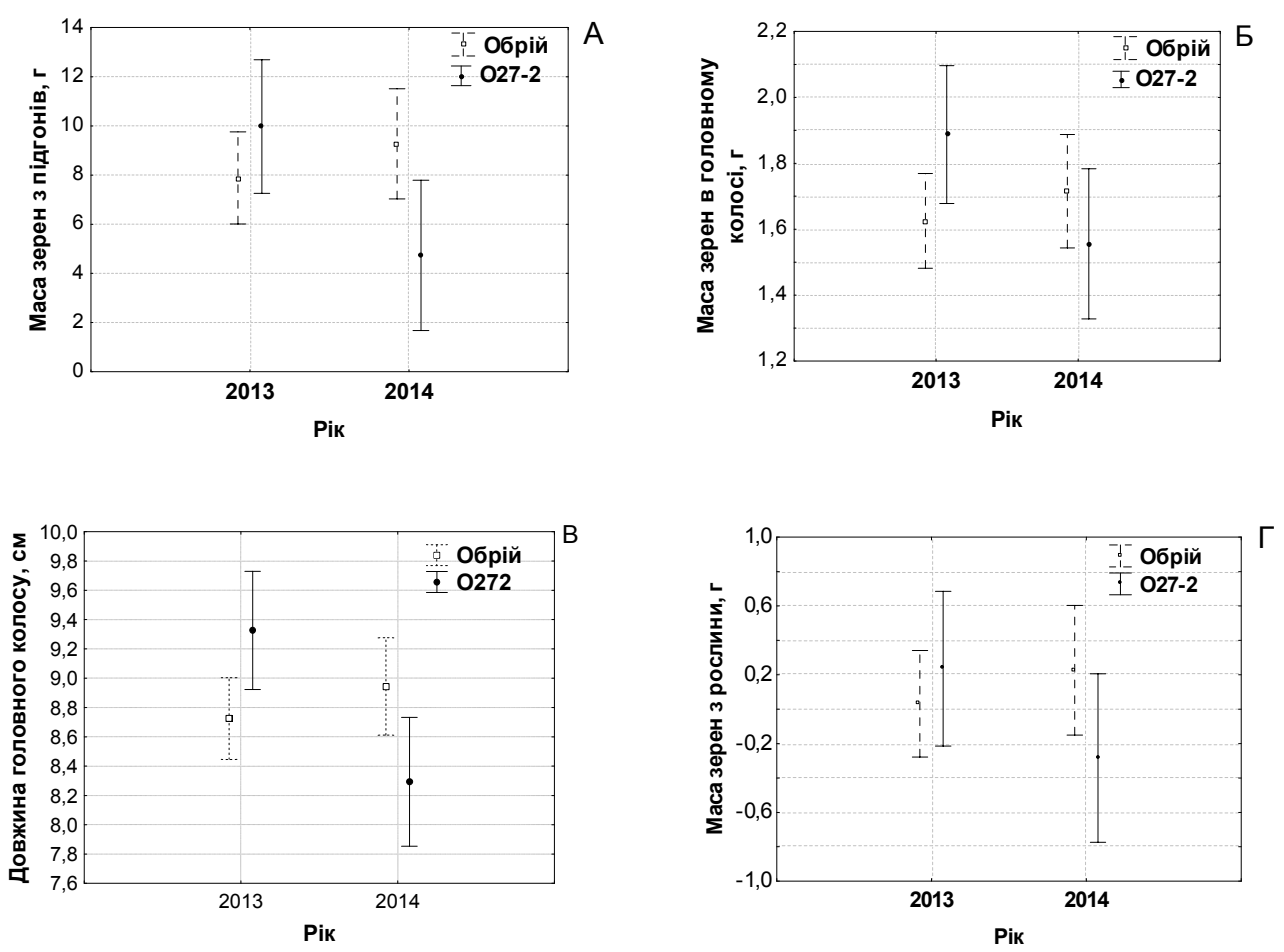

Рис. 3. Маса зерна з підгонів (А), маса зерна в головному колосі (Б), довжина головного колоса (B) та маса зерна з рослини (Г) в залежності від умов року та генотипу ліній

єю «Обрій», характеризувалася вищими показниками за наступними ознаками: маса тисячі зерен з рослини, маса тисячі зерен з підгонів та маса тисячі зерен 3 головного колосу. Інші показники (кількість зерен з підгонів, маса зерен з підгонів, кількість зерен з головного колосу, кількість фертильних колосків) були нижчими (табл. 2). Очевидно, це зумовлено присутністю доповненої хромосоми E. sibiricus в комплементі даного сорту.

Таблиця 2

Середні значення ознак ліній «Обрій» та «О27-2» за два роки дослідження

\begin{tabular}{|l|c|c|c|c|c|c|c|c|c|c|c|c|c|c|c|}
\hline Лінія & ВР & ККК & КФК & ЗК & МЗК & ЗП & МЗП & ЗР & МЗР & МТЗ & МТЗГ & МТЗП & ЩК & КСК & ЗКк \\
\hline $\begin{array}{l}\text { Обрій } \\
(\mathrm{n}=68)\end{array}$ & 76,4 & 21,9 & 20,1 & 57,1 & 1,7 & 313,9 & 8,6 & 375,5 & 10,2 & 26,9 & 29,3 & 25,9 & 23,8 & 1,8 & 2,8 \\
\hline $\begin{array}{l}\text { O27-2 } \\
(\mathrm{n}=35)\end{array}$ & 69,5 & 18,9 & 18,1 & 49,6 & 1,8 & 238,7 & 7,3 & 288,3 & 9,04 & 31,9 & 34,7 & 30,6 & 20,4 & 0,7 & 2,7 \\
\hline HІР $_{0,05}$ & 6,7 & $1,7^{*}$ & $2,3^{*}$ & 13,9 & $0,6^{*}$ & 220,4 & 6,9 & 229,7 & 7,2 & $4,3^{*}$ & $4,9^{*}$ & $4,9^{*}$ & 1,8 & 1,4 & 0,5 \\
\hline Р, \% & 0,8 & 0,7 & 1,1 & 2,1 & 2,4 & 6,5 & 7,2 & 6,1 & 6,3 & 1,3 & 1,4 & 7,3 & 0,7 & 8,7 & 1,5 \\
\hline
\end{tabular}

* n - кількість досліджених рослин 
Стійкість ліній «Обрій» і «О27-2» до інфекційних хвороб, бал

\begin{tabular}{|c|c|c|c|c|c|c|}
\hline Лінія & $\begin{array}{c}\text { Борошниста } \\
\text { роса }\end{array}$ & $\begin{array}{c}\text { Листова } \\
\text { іржа }\end{array}$ & Жовта іржа & $\begin{array}{c}\text { Стеблова } \\
\text { іржа }\end{array}$ & Септоріоз & Вжкя \\
\hline Обрій & $2-4 *$ & $1-3$ & $4-5$ & $3-4$ & $5-6$ & $3-5$ \\
\hline О27-2 & $2-4$ & $7-8$ & $4-5$ & $3-4$ & $5-6$ & $3-5$ \\
\hline
\end{tabular}

* Розмах варіації в роки дослідження

Окрім агрономічних ознак, визначалася стійкість ліній «Обрій» і «О27-2» до інфекційних хвороб (табл. 3). Фітопатологічна оцінка дала змогу визначити ступінь ураження дорослих рослин. Означені лінії характеризувалися однаково високою сприйнятливістю до борошнистої роси, жовтої та стеблової іржі, септоріозу і ВЖКЯ. Однак, лінії мали різні показники щодо стійкості до листової іржі. Лінія «О27-2» відзначалася високою стійкістю до даної інфекції, яка становить 7-8 балів, в той час виділена з сорту «Обрій» рекурентна лінія характеризувалася майже $100 \%$ ураженням рослин (1-3 бали).

\section{Висновки}

У вигляді доповнення до каріотипу сорту «Обрій» хромосома $\mathrm{S}^{\mathrm{t}}$ геному Elymus sibiricus, що кодує ознаки некротичної стійкості до листової іржі і сильного опушення верхньої поверхні листової пластинки, в умовах широкорядного посіву переважно негативно впливає на агрономічні ознаки пшениці (висоту рослин, кількість колосків в головному колосі, кількість фертильних колосків, кількість зерен в головному колосі). Проте, на ознаки: продуктивне кущення, довжина головного колоса, маса зерна з головного колосу, з підгонів і, в цілому, 3 рослини - означений вплив слабкий і суттєво модифікується умовами року. В цілому доповнена лінія характеризувалася вищою масою тисячі зерен, порівняно з рекурентною формою.

Означена хромосома суттєво підвищує стійкість рослин до листової іржі, проте ніяк не впливає на реакцію рослин на ураження борошнистою росою, жовтою і стебловою іржею, септоріозом, ВЖКЯ, до яких обидві лінії проявили сприйнятливість.

\section{Список використаної літератури}

1. Ауземус Э. Р. Генетика и наследование / Э. Р. Ауземус, Ф. Х. Мак-Нил, Ю. У. Шмидт; пер. с англ. Н. А. Емельяновой; под. ред. М. М. Якубцинера, Н. П. Козьминой, Л. Н. Любарского // Пшеница и ее улучшение. - М.: Колос, 1970. - С. 347-355.

2. Вакар Б. А. Пшенично-пырейные гибриды / Б. А. Вакар. - Львов, 1935. - № 8. - С. 121-162.

3. Голубовская И. Н. Цитология отдаленных гибридов пшеницы и перспективы их использования в селекции / И. Н. Голубовская; под ред. П. М. Жуковского, В. В. Хвостовой // Цитогенетика пшеницы и ее гибридов. - 1971. - С. 243-286.

4. Лакин Г. Ф. Биометрия / Г. Ф. Лакин. - М.: Высшая школа, 1973. -343 с. 
5. Крупнов В. А. Опушение листа пшеницы: генетические и экологические аспекты / В. А. Крупнов, А. П. Цапайкин // С.-х. биология. - 1990. - № 1. - С. 51-56.

6. Марков Л. I. Практикум із сільськогосподарської фітопатології: навчальний посібник / Л. І. Марков - К.: ННЦ ІАЕ, 2011. - 528 с.

7. Meтоды селекции и оценки устойчивости пшеницы и ячменя к болезням в странах-членах СЭВ / [Бабаянц Л. Т., Мештерхази А., Ветхер Ф. и др.]. - Прага, 1988. - 321 с.

8. Моррис Е. Р. Цитогенетика пшеницы и родственных форм / Е. Р. Моррис, Э. Р. Сирс; под ред. М. М. Якубцинера, Н. П. Кузьминой, Л. Н. Любарского // Пшеница и ее улучшение. - М.: Колос, 1970. - С. $33-102$.

9. Моцний I. I. Створення доповненої лінії пшениці з хромосомою від Elymus sibiricus / I. I. Моцний // Селекція та генетика сільськогосподарських рослин: традиції та перспективи: міжнар. наук. конф. до 100-річчя СГІ-НЦНС, 17-19 жовтня 2012 р. - Одеса, 2012. - С. 175-176.

10. Пальмова Е. Ф. Введение в экологию пшениц / Е. Ф. Пальмова. - М.-Л.: ОГИЗ, 1935. - 73 с.

11. Паушева 3. П. Практикум по цитологии растений / З. П. Паушева. - М.: Колос, 1980. - 304 с.

12. Пересыпкин В. Ф. Болезни сельскохозяйственных культур / В. Ф. Пересыпкин, Н. Н. Кирик, М. П. Лесовой и др.; под ред. В. Ф. Пересыпкина // Болезни зерновых и зернобобовых культур. - К.: Урожай, 1989. - Т. 1. -216 c.

13. Синиговеи M. Е. Перенесение устойчивости к ржавчине от пырея в пшеницу путем добавления и замещения хромосом / М. Е. Синиговец // Генетика. - 1976. - Т. 12, № 9. - С. 13-21.

14. Цицин Н. В. Вопросы отдаленной гибридизации растений / Н. В. Цицин // Генетика. - 1966. - № 10. $49 \mathrm{c}$.

15. Шаманин В. П. Изогенный метод в селекции яровой пшеницы на засухоустойчивость / В. П. Шаманин, И. Е. Лихенко // Изогенные линии культурных растений. - Новосибирск, 1991. - С. 81-91.

16. Catalogue of gene symbols for wheat / Wheat Genet. Symp. [Електронний ресурс] / [R.A. McIntosh, Y.Yamazaki, J. Dubcovsky et al.]. - Japan. - 2013. - Режим доступу: http//www.shigen.nig.ac.jp/wheat/komugi/ genes/download.jsp

17. Mujeeb-Kazi A. Progress in exploiting Aegilops tauschii for wheat improvement/A. Mujeeb-Kazi, R. Deldago, A. Cortes; Ann. Wheat Newsletter. - 2004. - V. 50. - P. 79-88.

18. Sears E. R. Transfer of alien genetic material to wheat. Wheat science today and tomorrow / E. R. Sears; ed. by L. T. Evans, W. J. Peacock. - Cambridge University Press, 1981. - P. 75-89.

19. Peto P. H.Hybridization of Triticum and Agropyron. Cytology of the male parents and F1 generation / P. H. Peto // Canad. J. Res. C. - 1936. - Vol. 14, № 5. - P. 203-214.

Стаття надійшла до редакції 08.02.2015

\section{И. И. Моцный ${ }^{1}$, И. С. Петрова ${ }^{2}$, Г. А. Чеботарь ${ }^{1}$, С. В. Чеботарь ${ }^{1,2}$,} ${ }^{1}$ Селекционно-генетический институт - Национальный центр семеноведения и сортоизучения, Овидиопольская дор., 3, Одесса, 65036, Украина

${ }^{2}$ Одесский национальный университет имени И. И. Мечникова, кафедра генетики и молекулярной биологии, ул. Дворянская, 2, Одесса, 65082, Украина

\section{ВЛИЯНИЕ ХРОМОСОМЫ ELYMUS SIBIRICUS НА АГРОНОМИЧЕСКИЕ ПРИЗНАКИ В ДИСОМНО- ДОПОЛНЕНОЙ ЛИНИИ ОЗИМОЙ МЯГКОЙ ПШЕНИЦЫ}

\section{Резюме}

Оценены различия между линей, выделенной из сорта озимой мягкой пшеницы «Обрий» и созданной на ее базе дисомно-дополненной линией «О27$2 »$, которая несет чужеродные признаки устойчивости к листовой ржавчине и опушения листовой пластинки от амфиплоида Elymus fertile. Определяли преимущественно негативное влияние чужеродной хромосомы на характеристики главного колоса (длина, количество колосков и зерен, масса зерна), высоту растений, количество и массу зерна с подгонов. Но на признаки: продуктивное 
кущение, длина главного колоса, количество колосков в главном колосе, масса зерна с главного колоса, с подгонов и, в целом, с растения - определенное влияние существенно модифицируется условиями года. Дополненная линия характеризовалась высшей массой тысячи зерен, в соответствии с рекуррентной формой. Указанная хромосома существенно повышает устойчивость растений к листовой ржавчине, однако никак не влияет на реакцию растений на поражение мучнистой росой, желтой и стеблевой ржавчиной, септориозом, ВЖКЯ, в которых обе линии проявили восприимчивость.

Ключевые слова: Triticum aestivum L., дополненные линии, количественные признаки.

\title{
I. I. Motsnyy ${ }^{1}$, I. S. Petrova ${ }^{2}$, G. O. Chebotar ${ }^{1}$, S. V. Chebotar ${ }^{1,2}$
}

${ }^{1}$ Plant Breeding and Genetics Institute - National Center of Seed and Cultivar investigations, 3, Ovidiopolska dor., Odesa, 65036, Ukraine

${ }^{2}$ Odesa National Mechnykov University, Department of Genetics and Molecular

Biology, 2, Dvoryanska str., Odesa, 65082, Ukraine

\section{EFFECTS OF CHROMOSOMES ELYMUS SIBIRICUS ON AGRONOMICAL TRAITS IN SUPPLEMENTED-DISOMNO LINES OF WINTER WHEAT}

\begin{abstract}
Summary
There were evaluated the differences between the line and grade «Obriy» created on its base disomno-supplemented line «O27-2», which was bearing the alien signs of resistance to leaf rust and the leaf trichomes on amfiploida Elymus fertile. It is mainly determined by the negative impact of alien chromosomes on the characteristics of the main spike (length, amount of spikelets and grains, grain weight), plant height, number and weight grains with the regrowth. But signs: productive tillering, the length of the main spike, amount of spikelets in the main spike, grain mass from the main spike, with the regrowth and, in general, with the plants - some is influence substantially modified by the conditions of the year. Supplemented line the higher was characterized by thousand kernel weight, in accordance with a recurrent form. Specified chromosome significantly increases plant resistance to leaf rust, but has no effect on the response of plants to be affected with powdery mildew, yellow and stem rust, septoria blight, barley yellow dwarf virus in which both lines showed susceptibility.
\end{abstract}

Key words: Triticum aestivum L., supplemented line, quantitative traits. 